\title{
SYNTHESIS AND CHARACTERIZATION OF NANO BIOTRICALCIUM SILICATE, AS A COMPONENT OF AN ENDODONTIC SEALER
}

\author{
LUCIA TIMIŞ ${ }^{\mathrm{a}}$, ALEXANDRA AVRAM ${ }^{\mathrm{b} *}$, MARIA GOREA ${ }^{\mathrm{b} *}$, \\ LILIANA BIZO ${ }^{\text {b }}$, SANDA CÎMPEAN ${ }^{\mathrm{a}}$, RADU SEPTIMIU CÂMPIAN"
}

\begin{abstract}
Endodontic sealers are designed to be used in conjunction with semi-rigid materials during endodontic treatment, in order to obtain a three dimensional obturation of the root canal. During the last years, tricalcium silicate $\left(\mathrm{C}_{3} \mathrm{~S}\right)$, due to its increased biocompatibility, and superior physicochemical properties, has been investigated as an important component of endodontic filling materials. For most materials available on the market the source of $\mathrm{C}_{3} \mathrm{~S}$ alongside $\mathrm{C}_{2} \mathrm{~S}$ is MTA (mineral trioxide aggregate), but obtaining $\mathrm{C}_{3} \mathrm{~S}$ through synthesis is considered to be a much better alternative due to its superior purity and controlled size of the particles. In this study $\mathrm{C}_{3} \mathrm{~S}$ was synthetized in nanosized particles, by sol-gel method, from TEOS and calcium nitrate tetrahydrate without or with mineralizer NaF. A study was conducted in order to analyze the obtained powder and the hydrated samples which were prepared by mixing the powder with water in a ratio of 0.4 , and cured for 28 days. The dried gels were thermally treated at $1450^{\circ} \mathrm{C}$ respectively at $1350^{\circ} \mathrm{C}$. XRPD and TEM revealed the main presence of nanosized tricalcium silicate besides dicalcium silicate and small quantities of calcium hydroxides at both of synthesis temperatures. The hydration compounds evidenced by XRPD were calcium silicate hydrate alongside calcium hydroxide and calcium carbonate. FTIR analysis evidenced the specific vibration bands for $\mathrm{O}-\mathrm{H}$ and $\mathrm{Si}-\mathrm{O}$ bounds in hydrated calcium silicates.
\end{abstract}

Keywords: endodontic sealer, calcium silicate

a Iuliu Hațieganu University of Medicine and Pharmacy, Faculty of Dentistry, Department of Odontology, 33 Moților str., RO-400001, Cluj-Napoca, Romania

b Babeş-Bolyai University, Faculty of Chemistry and Chemical Engineering, Department of Chemical Engineering, 11 Arany Janos str., RO-400028, Cluj-Napoca, Romania

c Iuliu Hațieganu University of Medicine and Pharmacy, Faculty of Dentistry, Department of Oral Rehabilitation, 15 Victor Babeș str., RO-400012, Cluj-Napoca, Romania

*Corresponding author: mgorea@chem.ubbcluj.ro; aavram@chem.ubbcluj.ro 


\section{INTRODUCTION}

Root canal obturation is the last phase of the endodontic treatment that will, if performed correctly, ensure the long-term success of the endodontic treatment [1]. The requirements for the ideal root canal filling material are multiple, and currently there is no such a material to fulfil all of them, even though there is a wide variety available on the market [2, 3].

In the last decades, as a progress in the field of nanotechnology new materials have been introduced in endodontics: bioceramic materials. Bioceramics are materials with increased biocompatibility such as alumina and zirconia, bioactive glass, glass ceramics, calcium silicates, calcium phosphates which can be biodegradable, bioinert or bioactive [4-6].

Tricalcium silicate $\left(\mathrm{C}_{3} \mathrm{~S}\right)$ is the main component of MTA (mineral trioxide aggregate), a cement with a similar composition with Portland cement, which has been successfully used in endodontic surgery and vital pulp therapy [7]. Lately $\mathrm{C}_{3} \mathrm{~S}$ was introduced as a main component of endodontic sealers, because of its outstanding biological and physicochemical properties.

Because endodontic obturation, will be in contact for a long period of time, with the periapical tissues, endodontic sealers which are genotoxic, mutagenic, carcinogenic will interfere with the periapical healing process. [8]. Compared to other materials, calcium silicate-based materials, due to their increased biocompatibility, do not induce an inflammatory response into periradicular tissues $[9,10]$.

Calcium silicate sealers exhibit excellent antibacterial properties better or at least similar to conventional sealers [2, 11, 12]. The lack of volumetric shrinkage upon setting, good adhesion to dentin, and lack of solubility makes them suitable for being placed in a moist environment [13]. Because of their hydrophilic properties, a certain amount of moisture is required to initiate the setting reaction, moisture that is provided by the dentine [14]. After the hydration process, a rigid matrix consisting of calcium silicate hydrates and calcium hydroxide is formed [15]. The calcium hydroxide released will exhibit antibacterial and anti-inflammatory properties and will induce bone mineralization [16, 17].

The bioactivity of calcium silicates was demonstrated in in vitro studies by the presence of a layer of calcium phosphates or even hydroxyapatite after soaking the samples in simulated body fluid (SBF) [18-20].

A large number of studies have been conducted in order to evaluate the properties of (tri)calcium silicates and the best method of their synthesis [21-25]. 
Most calcium silicate-based materials for endodontic use, which are available on the market, consist of MTA. In order to obtain a new material, more biocompatible, with better physicochemical properties, a lower setting time, and a controlled size of the particles, the synthesis of calcium silicates as a main component of endodontic sealers became a necessity.

The main purpose of this study was to synthetize bio nano tricalcium silicates $\left(\mathrm{C}_{3} \mathrm{~S}\right)$ from TEOS, $\mathrm{Si}\left(\mathrm{OC}_{2} \mathrm{H}_{5}\right)_{4}$, (tetraethyl orthosilicate) and $\mathrm{Ca}\left(\mathrm{NO}_{3}\right)_{2} \times 4 \mathrm{H}_{2} \mathrm{O}$ (calcium nitrate tetrahydrate) without or with mineralizer $\mathrm{NaF}$ by a sol-gel method, and characterize them for obtaining the endodontic sealer.

\section{RESULTS AND DISCUSIONS}

\section{Thermal analysis}

\section{Main thermal effects}

The thermal analysis curves (TG/DSC) for the gel without additive, dried at $250^{\circ} \mathrm{C}$, are displayed in Figure 1 , and those for the mixture with $\mathrm{NaF}$, dried at $120^{\circ} \mathrm{C}$, are shown in Figure 2. In both cases, a $10^{\circ} \mathrm{C} / \mathrm{min}$ heating rate up to $1400^{\circ} \mathrm{C}$ was performed.

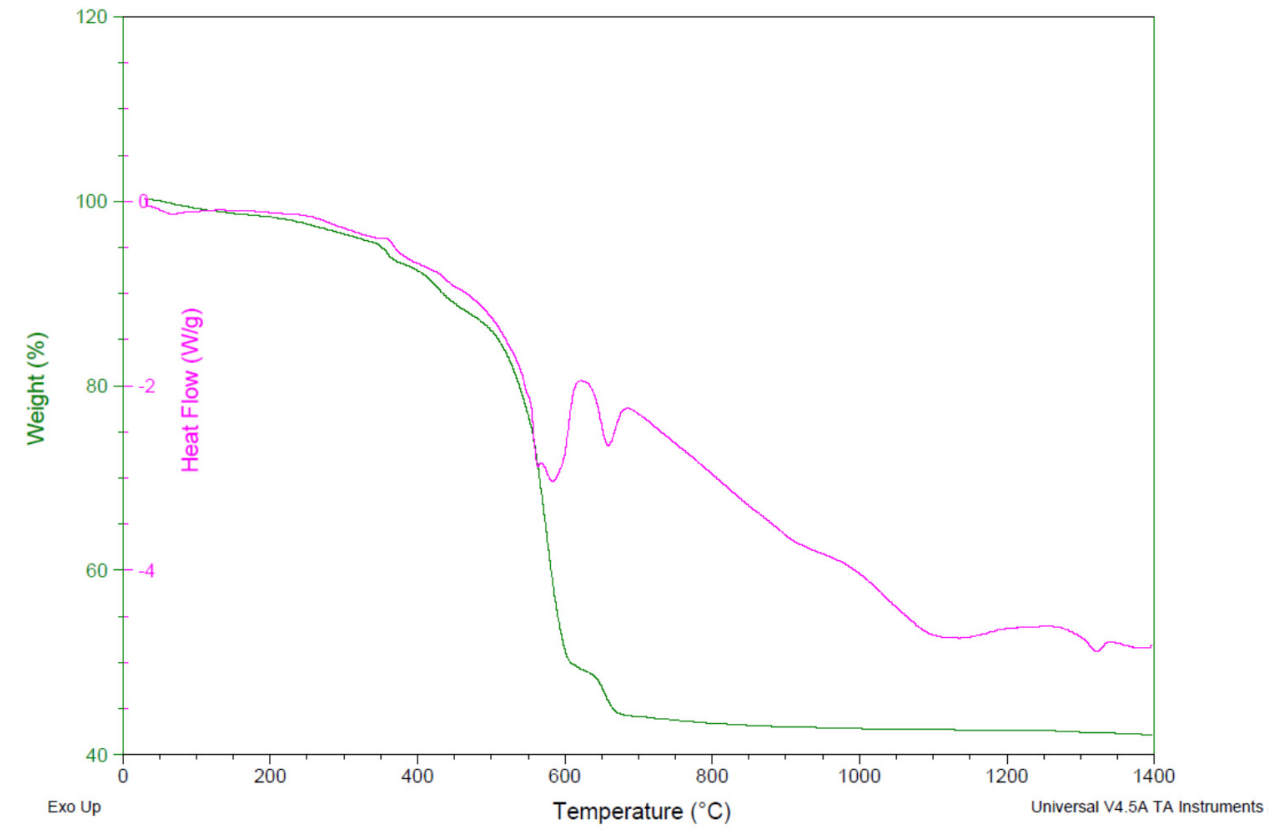

Figure 1. Thermal behaviour of dried gel $\left(250^{\circ} \mathrm{C}\right)$ without additive. 


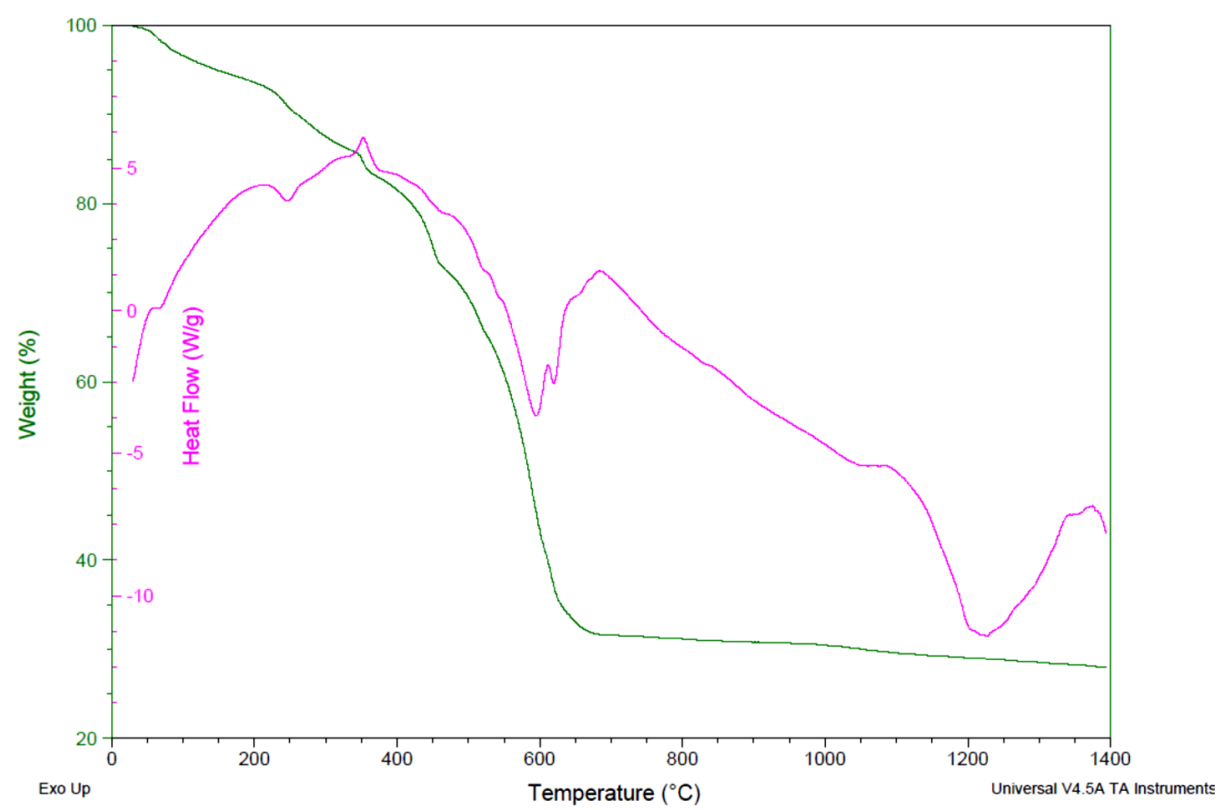

Figure 2. Thermal behaviour of dried gel $\left(120^{\circ} \mathrm{C}\right)$ with $\mathrm{NaF}$.

At lower temperatures $\left(T<200{ }^{\circ} \mathrm{C}\right)$ endothermic effects can be noticed, as a result of the removal of adsorbed water in the sample. In the 200-750 ${ }^{\circ} \mathrm{C}$ temperature range pronounced endothermic effects are visible, due to the elimination of hydrated water and decomposition of calcium nitrate tetrahydrate $\left(\mathrm{Ca}\left(\mathrm{NO}_{3}\right)_{2} \times 4 \mathrm{H}_{2} \mathrm{O}\right)$ and tetraethyl orthosilicate, $\mathrm{Si}\left(\mathrm{OC}_{2} \mathrm{H}_{5}\right)_{4}$ (TEOS). The large exothermic peak that can be observed at about $1000^{\circ} \mathrm{C}$, corresponds to the crystallization of dicalcium silicates and the-one at around the $1300{ }^{\circ} \mathrm{C}$ is attributed to the formation of tricalcium silicate.

The total weight loss for the sample without mineralizer, dried at 250 ${ }^{\circ} \mathrm{C}$ is $57.59 \%$, and for the sample with $\mathrm{NaF}$ dried at $120^{\circ} \mathrm{C}$ is $72 \%$.

\section{X-ray powder diffraction (XRPD) of synthetized powders}

The XRPD patterns of synthesized calcium silicates at $1450{ }^{\circ} \mathrm{C}$ and $1350{ }^{\circ} \mathrm{C}$ are presented in Figure $3 \mathrm{a}$ and $\mathrm{b}$. The phase composition of the thermally treated powders, determined by XRPD, revealed the main presence of tricalcium silicate $\left(\mathrm{C}_{3} \mathrm{~S}\right)$, besides dicalcium silicate $\left(\mathrm{C}_{2} \mathrm{~S}\right)$ and calcium hydroxide $\mathrm{Ca}(\mathrm{OH})_{2}$, as a result of hydration of calcium oxide, $\mathrm{CaO}$. The presence of dicalcium silicate and calcium hydroxide indicates an incomplete reaction between reactants, but their presence in endodontic sealer would not be harmful to human cells. 


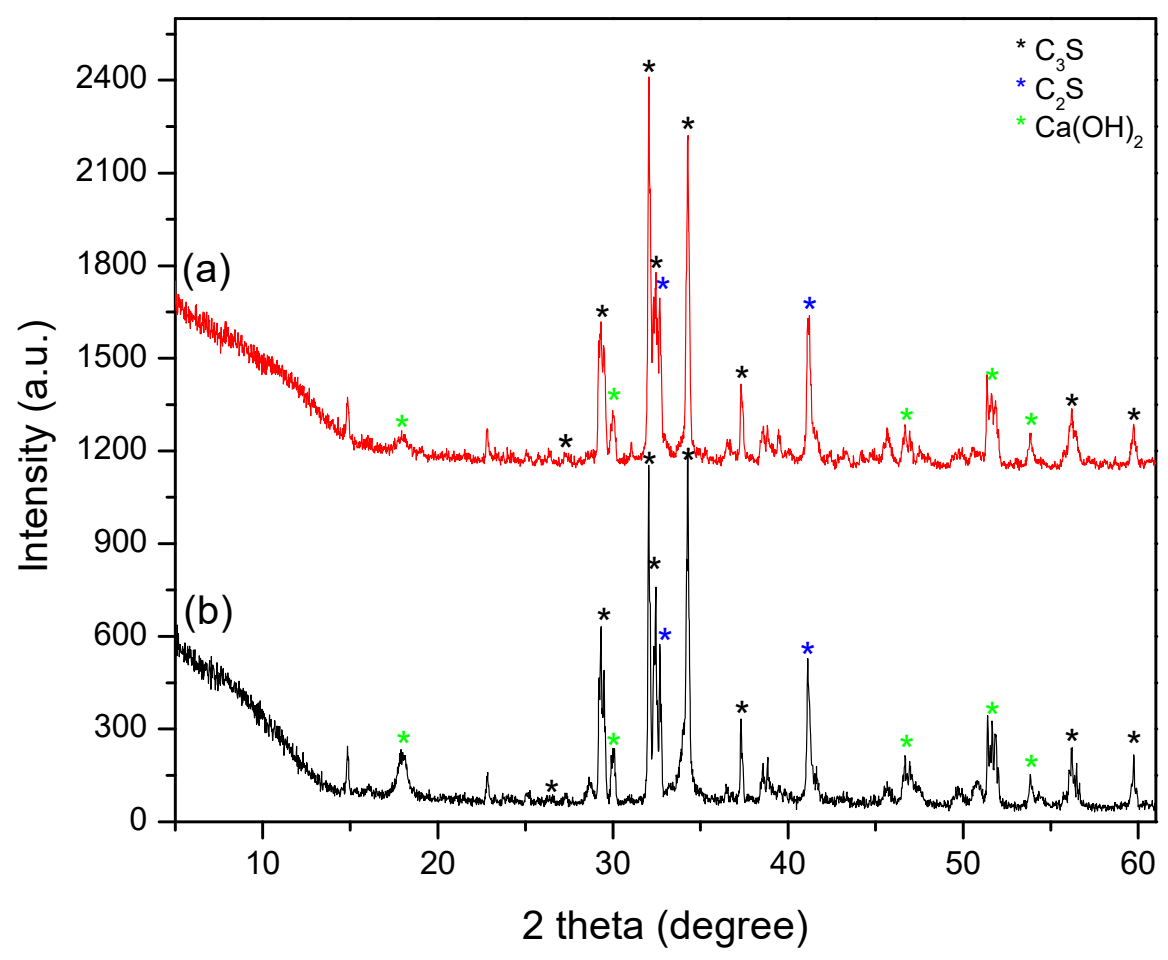

Figure 3. XRPD patterns for the (a) $1450^{\circ} \mathrm{C}$ and (b) $1350^{\circ} \mathrm{C}$ synthesized samples.

The crystallite sizes of tricalcium silicate were calculated from XRPD data using Scherrer formula. The average values for the $\mathrm{C}_{3} \mathrm{~S}$ obtained at $1450{ }^{\circ} \mathrm{C}$, was $41.51 \mathrm{~nm}$ and those for $\mathrm{C}_{3} \mathrm{~S}$ with mineralizer obtained at $1350^{\circ} \mathrm{C}$ was $54.78 \mathrm{~nm}$.

\section{Transmission electron microscopy (TEM)}

TEM was used to illustrate the shape and morphology of mineral compounds. The presence of rhombohedral well-developed, nanometricsized crystals of tricalcium silicate, besides of small quantities of hexagonal crystals of dicalcium silicate are illustrated in Figure 4. 


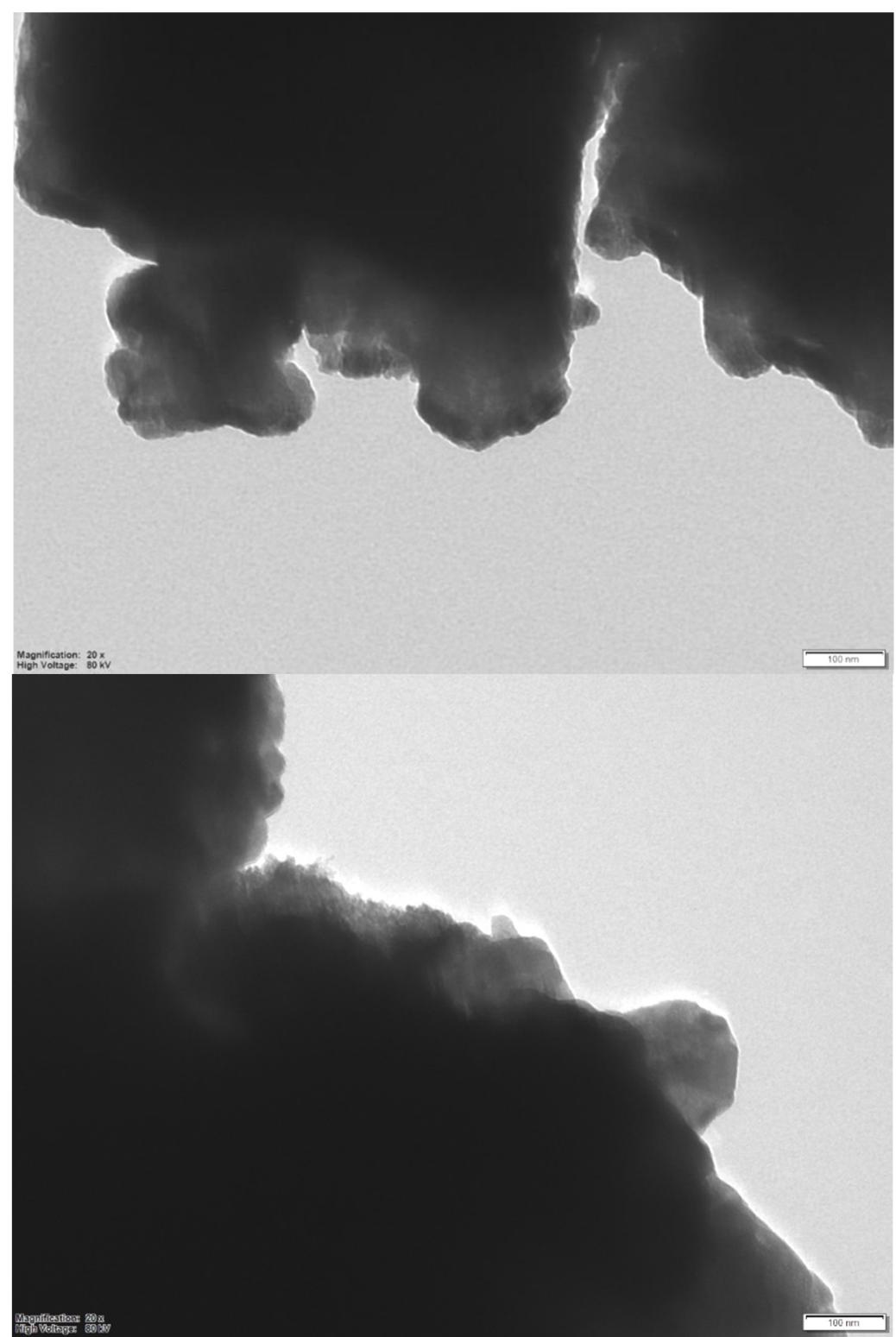

Figure 4. TEM image of tricalcium silicate powder synthesized at $1450^{\circ} \mathrm{C}$ (up) and $1350^{\circ} \mathrm{C}$ (down).

Figure 4 (up) presents the shape and sizes of the powder synthesised at $1450^{\circ} \mathrm{C}$ and figure 4 (down) for the powder obtained at $1350^{\circ} \mathrm{C}$. No differences can be observed in the characteristics of the calcium silicates minerals. Both syntheses led to rhombohedral shapes and nanometric sizes for tricalcium silicates. 


\section{Hydration mechanism of calcium silicates}

In order to facilitate the use of calcium silicates as endodontic sealers, they have to be mixed with aqueous solutions. This ensures hardening which comes due to the crystallization of calcium silicate hydrates.

Calcium silicates hydration determines protons fixation, so $\mathrm{O}^{2-}$ is changed into $\mathrm{HO}^{-}, \mathrm{SiO}_{4}{ }^{4-}$ in $\mathrm{H}_{\mathrm{n}} \mathrm{SiO}_{4}{ }^{(n-4)}, \mathrm{Ca}^{2+}$ ions in $\mathrm{Ca}^{2+} \mathrm{Aq}$. $\mathrm{HO}^{-}$and $\mathrm{Ca}^{2+}$ ions migrate in solution and a calcium silicate hydrate (CSH) layer is formed on the calcium silicate surface. This layer is preponderantly constituted from $\mathrm{H}_{3} \mathrm{SiO}_{4}^{-}$and $\mathrm{H}_{4} \mathrm{Si}_{2} \mathrm{O}_{7}{ }^{2-}$ ions.

The schematic reactions of tri- and dicalcium silicates are illustrated in Eq. 1 and 2.

$$
\begin{array}{ll}
\underset{\mathrm{C}_{3} \mathrm{~S}}{2\left(\mathrm{Ca}_{3} \mathrm{Si}_{2} \mathrm{O}_{7}\right)}+6 \mathrm{H}_{2} \mathrm{O} & \rightarrow \underset{\mathrm{Ca}_{3} \mathrm{Si}_{2} \mathrm{O}_{7} \cdot 3 \mathrm{H}_{2} \mathrm{O}+3 \mathrm{Ca}(\mathrm{OH})_{2}}{\mathrm{CSH}} \\
2\left(\mathrm{Ca}_{2} \mathrm{Si}_{2} \mathrm{O}_{4}\right)+4 \mathrm{H}_{2} \mathrm{O} & \rightarrow \underset{\mathrm{Ca}_{3.3} \mathrm{Si}_{2} \mathrm{O}_{7} \cdot 3 \mathrm{H}_{2} \mathrm{O}+0.7 \mathrm{Ca}(\mathrm{OH})_{2}}{\mathrm{CSH}}
\end{array}
$$

During the hydration, the thickness of the calcium silicate hydrate (CSH) layer and the index of crystallinity are increased. The hydration process is slow depending on the diffusion rate of the ions inside the new formed layer and the ion change from solid to solution.

\section{XRPD of hydrated calcium silicates}

The XRPD patterns of synthetized samples at $1450{ }^{\circ} \mathrm{C}$, after the hydration process, cured for 28 days in $90 \%$ relative humidity at $22{ }^{\circ} \mathrm{C}$, and $37^{\circ} \mathrm{C}$, are shown in Figure $5 \mathrm{a}$ and $\mathrm{b}$. 


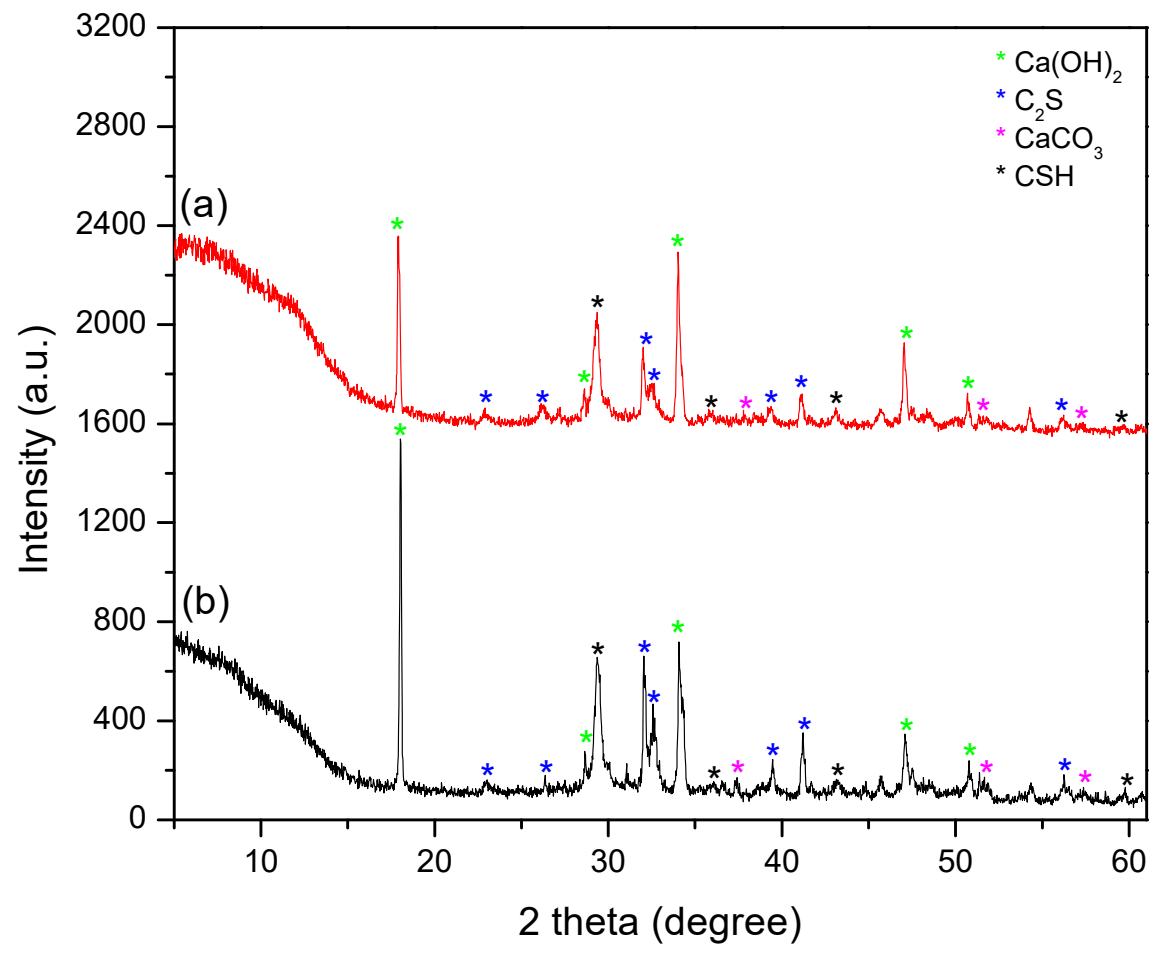

Figure 5. XRPD patterns for samples cured for 28 days at (a) $22^{\circ} \mathrm{C}$ and (b) $37^{\circ} \mathrm{C}$.

The hydration compounds evidenced by XRPD are hydrated calcium silicate (CSH) alongside calcium hydroxide, calcium carbonate and dicalcium silicate $\left(\mathrm{C}_{2} \mathrm{~S}\right)$. The crystallinity index of $\mathrm{CSH}$ is low for both samples due to the short time of hydration, higher for the sample cured at $37^{\circ} \mathrm{C}$ (Figure $4 \mathrm{~b}$ ). The calcium hydroxide is evidenced in the pattern as a hydration product of calcium silicates. The presence of $\mathrm{CO}_{2}$ in the environment and its partial reaction with $\mathrm{Ca}(\mathrm{OH})_{2}$ explains the presence of $\mathrm{CaCO}_{3}$ crystals. As observed from Figure $5, \mathrm{C}_{2} \mathrm{~S}$ is present in both samples. The presence of $\mathrm{C}_{2} \mathrm{~S}$ could be due to its long-time necessity for hydration or due to its high grain size.

The crystallite sizes of calcium silicates hydrates were calculated from XRPD data using Scherrer formula. The average values were $26.59 \mathrm{~nm}$ for samples cured at $22^{\circ} \mathrm{C}$ and $22.39 \mathrm{~nm}$ for samples cured at $37^{\circ} \mathrm{C}$. 


\section{FTIR analysis for hydrated calcium silicates}

The FTIR spectra for hydrated calcium silicates, after the hydration process, cured at $22{ }^{\circ} \mathrm{C}$ respectively at $37^{\circ} \mathrm{C}$ for 28 days, are presented in Figure $6 \mathrm{a}$ and $\mathrm{b}$.

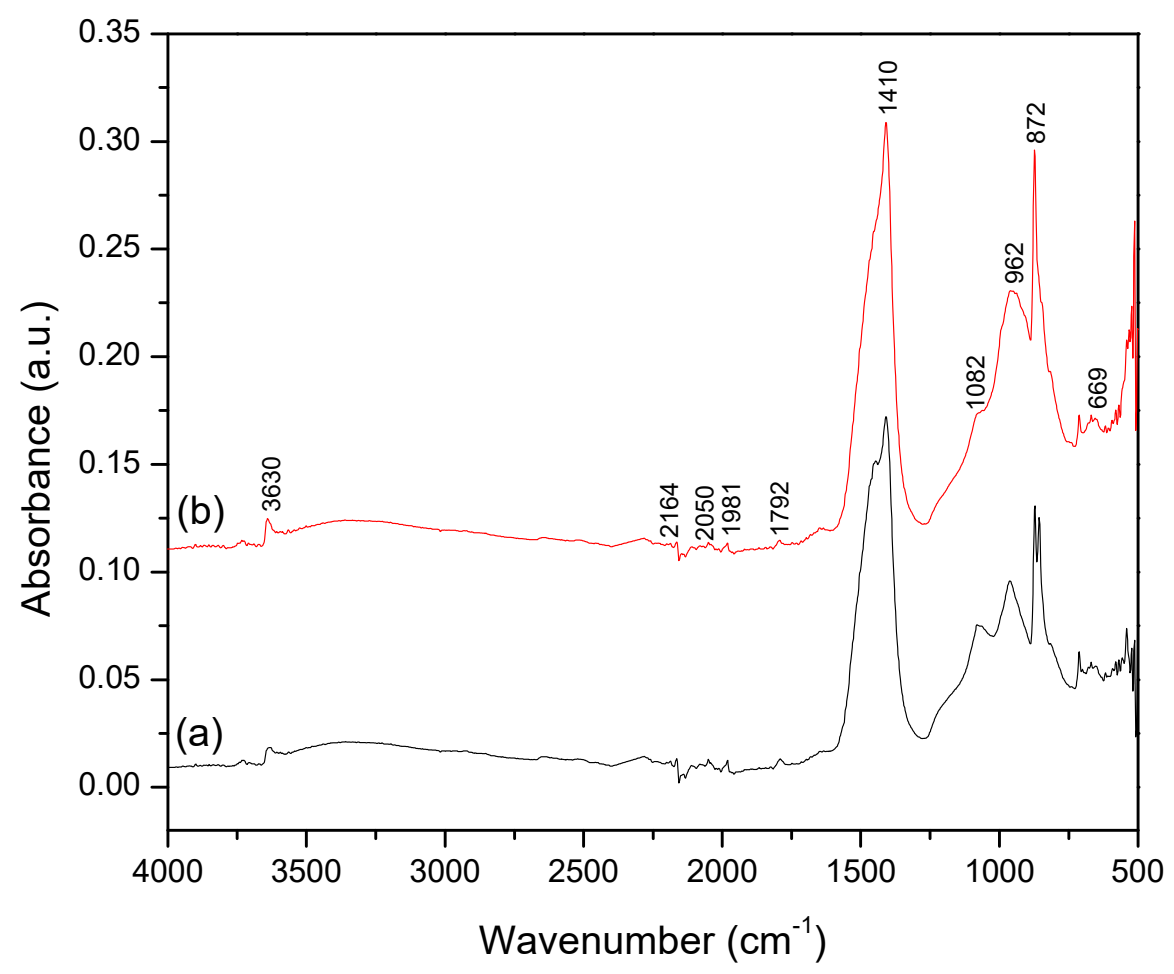

Figure 6. FTIR spectra for $\mathrm{C}_{3} \mathrm{~S}$ cements cured for 28 days at (a) $22^{\circ} \mathrm{C}$ and (b) $37^{\circ} \mathrm{C}$, respectively.

Due to the hydration process two broad absorption bands around the $1400-1600 \mathrm{~cm}^{-1}$ and $3400-3600 \mathrm{~cm}^{-1}$ are caused by the bending vibration of bound water incorporated in hydrated calcium silicates. The peak at $3630 \mathrm{~cm}^{-1}$ corresponds to $\mathrm{Ca}(\mathrm{OH})_{2}$, which is formed during the hydrolysis of silicate phases 
The specific vibration bands of $\mathrm{Si}-\mathrm{O}$ bonds from $\mathrm{SiO}_{4}$ groups for silicates can be evidenced. High spectral intensity bands are observed from $\sim 900 \mathrm{~cm}^{-1}$ to $\sim 1000-1100 \mathrm{~cm}^{-1}$, which suggests some rearrangements in the silica subsystem in the presence of water. These features reflect the dissolution of calcium silicates $\left(\mathrm{C}_{3} \mathrm{~S}, \mathrm{C}_{2} \mathrm{~S}\right)$ and the polymerization of calcium silicate hydrate $\mathrm{CSH}$. The small absorption band around $1081 \mathrm{~cm}^{-1}$ could be attributed to both the vibration of the $\mathrm{CO}_{3}{ }^{-}$group in the newly formed carbonates and the stretching vibration of $\mathrm{Si}-\mathrm{O}$ bound in calcium silicate hydrates.

\section{CONCLUSIONS}

Tricalcium silicate $\left(\mathrm{C}_{3} \mathrm{~S}\right)$, was successfully synthetized at $1450{ }^{\circ} \mathrm{C}$ respectively $1350^{\circ} \mathrm{C}$ from TEOS and calcium nitrate tetrahydrate without and with mineraliser by a sol-gel method.

X-ray powder diffraction (XRPD) revealed the main presence of tricalcium silicates $\left(\mathrm{C}_{3} \mathrm{~S}\right)$, alongside dicalcium silicate $\left(\mathrm{C}_{2} \mathrm{~S}\right)$ and small quantities of calcium hydroxides $\mathrm{Ca}(\mathrm{OH})_{2}$, at both synthesis temperatures. In samples cured for 28 days, the compounds evidenced by XRPD were calcium silicate hydrates $(\mathrm{CSH})$, calcium hydroxide $\mathrm{Ca}(\mathrm{OH})_{2}$ and calcium carbonate $\mathrm{CaCO}_{3}$.

FTIR spectroscopy confirmed the presence of specific bands corresponding to the hydrated compounds in the solid. TEM images showed the well-developed nanocrystals of tri- and dicalcium silicates.

The data obtained revealed that the powder consists mainly of nanosized tricalcium silicates, with a good hydration rate, making it suitable for endodontic use.

\section{EXPERIMENTAL PART}

\section{Synthesis of tricalcium silicate}

In order to synthesize tricalcium silicate $\left(\mathrm{Ca}_{3} \mathrm{SiO}_{5}\right)$, calcium nitrate tetrahydrate $\left(\mathrm{Ca}\left(\mathrm{NO}_{3}\right)_{2} \times 4 \mathrm{H}_{2} \mathrm{O}, 99.5 \%\right.$ purity, Merck) and tetraethyl orthosilicate, (TEOS - $\mathrm{C}_{8} \mathrm{H}_{20} \mathrm{O}_{4} \mathrm{Si}$, Merck), were used as main raw materials. Ethanol $\left(\mathrm{C}_{2} \mathrm{H}_{5} \mathrm{OH}\right)$ and nitric acid $\left(\mathrm{HNO}_{3}\right)$ were used as $\mathrm{pH}$ regulators. In order to reach calcium silicate stoichiometry the molar ratio of $\mathrm{CaO} / \mathrm{SiO}_{2}$ was established at $3 / 1$. 
The flowchart of steps involved in the tricalcium silicate synthesis is presented in Figure 7.

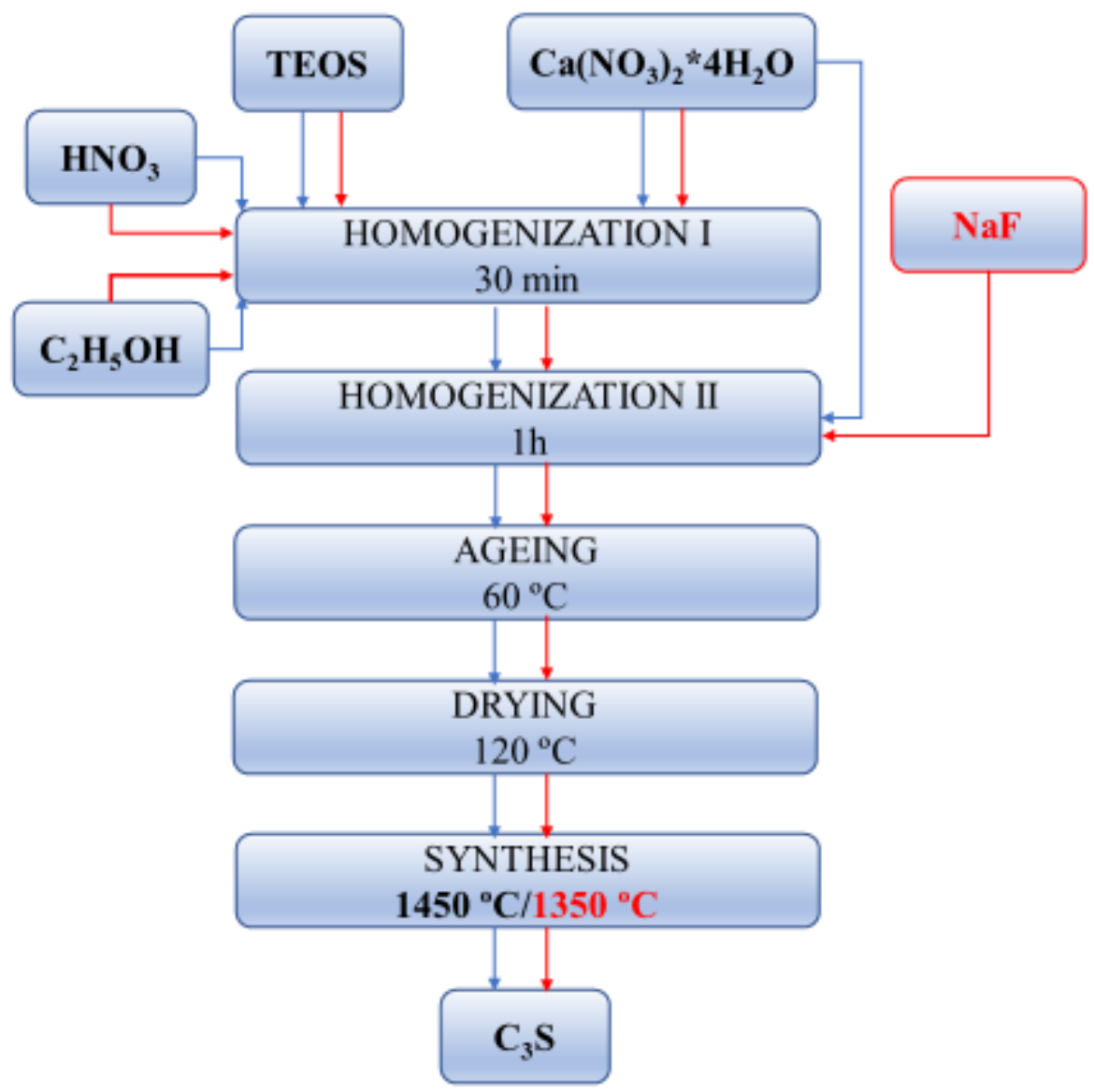

Figure 7. The synthesis flow chart of tricalcium silicate $\left(\mathrm{C}_{3} \mathrm{~S}\right)$.

The homogenized mixture of TEOS, calcium nitrate, ethanol, and nitric acid, was dried at $60^{\circ} \mathrm{C}$ for gelation. The resulted gel was further dried at $120^{\circ} \mathrm{C}$ and, afterwards, thermally treated at $1450^{\circ} \mathrm{C}$ for 4 hours.

In the other mixture, in order to facilitate the reaction between compounds and to reduce the temperature of thermal treatment, an additive of $\mathrm{NaF}(1 \%)$ was added in the homogenization step. After drying the obtained gel was thermally treated in two steps: at $600^{\circ} \mathrm{C}$ for 6 hours and at $1350{ }^{\circ} \mathrm{C}$ for 30 minutes. 


\section{Characterization of $\mathrm{C}_{3} \mathrm{~S}$ powder}

\section{$X$-ray powder diffraction (XRPD)}

The phase composition of $\mathrm{C}_{3} \mathrm{~S}$ powder was determined using a Bruker D8 Advance diffractometer, with Co, $\mathrm{K} \alpha_{1}=1.79026 \AA$, operated at 35 $\mathrm{kV}$ and $40 \mathrm{~mA}$. The pattern was collected for $2 \theta$ range from $5^{\circ}$ to $65^{\circ}$, with a step size of $0.02 \%$ sec.

\section{Transmission Electron Microscopy (TEM)}

The size and shape of calcium silicate crystallites were investigated by TEM on HITHACHI H-7650 equipment.

\section{Thermal analysis}

The thermal behaviour of gels obtained by the sol-gel method, was studied by thermal analysis, conducted by the thermogravimetric (TG) and differential scanning calorimetry (DSC) using a TA Instruments DSC SDT Q600 thermogravimetric analyser.

\section{Fourier transform infrared (FTIR) spectroscopy}

The FTIR absorption spectra were recorded with a JASCO V670 UV-Vis-NIR spectrophotometer.

\section{REFERENCES}

1. J. Branstetter; J.A. von Fraunhofer; J. Endod., 1982, 8(7), 312-316.

2. H.M. Zhou; Y. Shen; W. Zheng; L. Li, Y.F. Zheng, M. Haapasalo, J. Endod., 2013, 39(10), 1281-1286.

3. D. Orstavik, Endodontic Topics, 2005, 12(1), 25-38.

4. S. Utneja; R.R. Nawal; S. Talwar; M. Verma; Restor. Dent. Endod., 2015, 40(1),1-13.

5. K. Koch; D. Brave, Dentaltown, 2009, 39-43.

6. L. Bizo; K. Sabo; R. Barabas; G. Katona; L. Barbu-Tudoran; A. Berar; Studia UBB Chemia, LXV, 1, 2020, 137-148.

7. N. Meschi, X. Li, G. Van Gorp, J. Camilleri, B. Van Meerbeek, P. Lambrechts, Dent Mater. 2019, 35(9), 1342-1350.

8. F.C. Martinho; S.E.A. Camargo; A.M.M. Fernandes; M.S. Campos; R.F. Prado; C.H.R. Camargo; M.C. Valera; International Endodontic Journal, 2018, 51, 41-57.

9. D. Brave; A.A. Nasseh; K. Koch; Roots, 2013, 4(4), 6-12.

10. E.J. Silva; P.M. Senna; G. De-Deus; A.A. Zaia; Int. Endod. J., 2016, 49(6), 574 580.

11. S. Jitaru; I. Hodisan; L. Timis; A. Lucian; M. Bud; Clujul Med., 2016, 89(4), 470473. 
SYNTHESIS AND CHARACTERIZATION OF NANO BIOTRICALCIUM SILICATE, AS A COMPONENT OF AN ENDODONTIC SEALER

12. H. Zhang; Y. Shen; N.D. Ruse; M. Haapasalo; J. Endod., 2009, 35(7),10511055.

13. A. Avram; M. Gorea; R. Balint; L. Timiș; S. Jitaru; A. Mocanu; M. TomoaiaCotișel; Studia UBB Chemia, LXII, 4, Tom I, 2017, 81-92.

14. G.C. Gritti; S.I.A. Cavalcante; E.M. Maia-Filho; J. Bauer; M.C. Bandéca; G. Gavini; C.N. Carvalho; Braz. Oral Res., 2017, 31, e76.

15. B. Darvell; R.C.T. Wu; Dent. Mater., 2011, 27, 407-422.

16. H.K. El-Hamid; H.H. Abo-Almaged; M.M. Radwan; J. App. Pharm. Sci., 2017, 7(10), 001- 008.

17. A. Koutroulis, S.A. Kuehne, P.R. Cooper, J. Camilleri, Sci. Rep., 2019; 9, 19019.

18. W. Zhao, J. Chang, Mater. Lett., 2004, 58, 2350-2353.

19. X. Liao, H. Zhu, G. Yin, Z. Huang, Y. Yao, X. Chen, Bull. Mater. Sci., 2011, 34, $1151-1155$.

20. M.C. Jimenez-Sanchez; J.J. Segura Egea; A. Diaz-Cuenca; J. Clin. Exp. Dent. 2019, 11(4), e322-326.

21. M. Wu; T. Wang; Y. Wang; F. Li; M. Zhou; X. Wu; Mater. Lett., 2018, 227, 187190.

22. P. Torkittikul, A. Chaipanich, Mater. Sci. Eng. C, 2012, 32, 282-289.

23. K.B. Wiltbank, S.A. Schwartz, W.G. Schindler, J. Endod., 2007, 33(10), 12351238.

24. L. Wang, X. Xie, C. Li, H. Liu, K. Zhang, Y. Zhou, X. Chang, H.H. K. Xu., J. Dent., 60, 2017, 25-35.

25. L. Grech, B. Mallia, J. Camilleri, Dent. Mater., 29, 2013, 20-28. 